\title{
IMPROVING THE QUANTITY AND QUALITY OF SUDANGRASS GROWN IN SALT AFFECTED SOILS USING GYPSUM AND BIO-FEUTILIZATION
}

\author{
Azza Kh. Salem ${ }^{(1)}$, Fadia M. Sultan ${ }^{(1)}$ and Seham Y.M. Abo-Steet ${ }^{(2)}$ \\ (1) Forage Crops Res.Depart.,Field Crops Res. Inst.,Agri.Res.Center, Giza,Egypt. \\ (2) Soils,Water and Environment Res.Inst., Agri.Res.Center, Giza,Egypt
}

Received: Nov. 21, 2016

Accepted: Jan. 3, 2017

\begin{abstract}
A field experiment was carried out at El-Serw Station Damietta Governorate Agric. Res. Center during two summer seasons of 2014 and 2015. The present investigation aimed to increase fodder productivity of sudangrass (sorghum bicolor (L.)var. sudanense( piper cv.) under such saline soil and investigate the possibility of partial replacement of $\mathrm{N}$ fertilizer by the application some soil amendments. The amendment gypsum was added at 4 ton $\mathrm{fed}^{-1}$ or without and three $\mathrm{N}$-fertilizer levels $\left(30,60\right.$, and $\left.90 \mathrm{~kg} \mathrm{fed}^{-1}\right)$ under two bio-fertilization treatments (inoculation and uninoculation).

The obtained results were summarized as follows:

1-Application gypsum to salt affected soils promotes the use efficiency of $\mathrm{N}$-fertilizer which was reflected to plant height, fresh and dry yield and gave the better nutritive content as compared to without gypsum. In this concern, the application of 4 ton gypsum fed ${ }^{-1}$ gypsum and $90 \mathrm{~kg} \mathrm{~N}$ $\mathrm{fed}^{1}$ with inoculation gave the highest increments of yield quantity and quality parameters under study.

2-Gypsum decreased soil $\mathrm{pH}$ and EC, both soluble and exchangeable sodium. However, increased soluble and exchangeable calcium.

3-Application of $\mathrm{N}$ fertilizer at $60 \mathrm{~kg} \mathrm{fed}^{-1}$ with bio-fertilizer gave no significant results with those obtained when plants were fertilized by the high level of $90 \mathrm{~kg} \mathrm{~N} \mathrm{fed}^{-1}$ alone without biofertilizer.

4-Inoculation with nitrobein was resulted significant increases in plant height, fresh and dry yield, and crude protein content compared to untreated.

The results could be concluded that the application of 4 ton gypsum fed ${ }^{-1}$ and $60 \mathrm{~kg} \mathrm{~N} \mathrm{fed}^{-1}$ with nitrobein inoculation was the best treatment to sudangrass under the condition of salt affected soils for increasing fodder productivity and quality as well as improving soil characters.
\end{abstract}

Key words: Gypsum, N-fertilizer levels, nitrobein, Salt affected soils, sudangrasses.

\section{INTRODUCTION}

Agricultural production becomes imperative for establishment of the relationships between crop productivity and soil characteristics. More effective using of amendments for improving the soil fertility, enhancing organic matter. (Kusvuran et al., 2014). In Egypt, the production of green forage is less than the demand, which effect meat and milk production. Moreover, the acute shortage of feed during summer season (Hathout, 1987). Crop production needs to be increased substantially to reduce food insecurity. Since most soils in the region are inherently poor, external inputs such as mineral or organic fertilizers are necessary to boost crop production. However, marginal farmers do not use sufficient amounts of mineral fertilizers for various reasons (Manyong et al., 2001). In addition, there is a real need to improve crop productivity in an ecofriendly manner. This has led to the promotion of commercial biological and chemical products to restore and enhance the fertility and organic matter content of soils. Therefore, microorganisms are important component of integrated nutrient management systems and soil 
biodiversity. It is assumed that many of the biological products being offered to farmers which contain beneficial microorganisms (bacteria and fungi) (Larkin et al., 1993). This is an integral aspect of soil conditioning. Although there is evidence that rhizobia and mycorrhizal inoculants can improve the yield of certain crops (Giller, 2001).

Fertilizers constitute an integral part of improved crop production technology. The proper amount of fertilizer application is considered a key to crop production. On the other hand, using fertilizer is profitable until yield increasing rate adequate cost. Using much $\mathrm{N}$ can result in problems such as much cost, soil degradation and pollution (Alcoz et al., 1993). Nitrogen is an essential element required for plant growth in relatively large amounts. Nitrogen deficiency reduced dry matter, crude protein and grain crude fiber. In fodder crops, $\mathrm{N}$ fertilizer increased crude protein. Therefore, it seems that application of $\mathrm{N}$ fertilizer increase palatability and digestibility of fodder. On the other hand, amount of soluble carbohydrates also could alter the quality of the forages (Almodares et al., 2009). Mousavi, et al. (2012) recommended that the applied of 135 to $225 \mathrm{~kg} \mathrm{~N}^{-1}$ to sorghum plants was improved grow extensively during summer season.

Bio-fertilizers are used for increasing soil productivity and plant growth in sustainable agriculture (Canbolat et al., 2006). Microorganisms are also important to promote the circulation of plant nutrients and reduce the need of much chemical fertilizer (Cakmakç et al., 2006). Javaid and Mahmood (2010) showed that when effective cultures of microorganisms are applied to the soil, the decomposition of organic wastes and residues thereby releasing inorganic nutrients that become available for uptake by the plants. Promoting bacteria can affect plant growth and yield because of its interaction with soil characteristics and nutrient availability (Yazdani et al., 2009). The effect of PGPR, as a complex process, depends on bacterial strains and population, plant-bacterial strain combination, plant genotype, growth parameters evaluated, and environmental conditions (Şahin et al., 2004 and Cakmakç et al., 2007). Gypsum is an excellent kickstarter; grains in crop production and longerterm improvement in soil structure through amelioration of solicity if application and other soil amendment practices are combined. Many investigators reported that gypsum had a good effect on improving soil physical and chemical properties and led to increasing nutrient availability in soil which reflected on yield (El-Sharawy et al .,2008).

The increase of $\mathrm{N}$ fertilizer led to increase nitrate content in the crop tissues without significant increase in yield (Custic et al., 1994) and led to high cost of production, creates pollution of agricultural environment as well as affects the soil fertility. Salem (2003) found that using chemical amendments such as gypsum was improved the poor physical, chemical and biological properties in salt affected soils. Nitrogen is one of the major nutrients for cereals to producing the economic yield. It's essential role may be attributed to one or all of these reasons: 1) nitrogen is constituent of all proteins and nucleic acids and hence of all protoplasm. (Russell, 1973) nitrogen enhances the meristematic activities consequently, increasing the cell size that manifested in internodes elongation, (Osman et al.,2000) nitrogen increases the nutrients uptake, capacity of photosynthesis assimilation in building metabolites, its translocation and accumulation in the sink (Fathi et al.,2003).

Therefore, the present investigation was undertaken to study the possibility of the partial replacement of require mineral nitrogen fertilizer by the application of gypsum and nitrobein on fodder productivity and quality sudangrasses grown in salt as well as improving the poor soil physical, chemical and biological characteristics. 


\section{MATERIALS AND METHODS}

Experiment layout : A field experiment was carried out at El-Serw Agricultural Experiment and Research Center, Damietta Governorate, Egypt. (31을 $22^{\prime}$ latitude and $31^{\circ} 64^{\prime}$ Longitude) during two successive summer seasons of 2014 and 2015 to study the effectiveness of gypsum, nitrogen and bio- fertilizer treatments (nitrobein) on productivity and quality of sudangrass before sowing, surface soil sample (0-30 $\mathrm{cm}$ ) of the experimental was taken, air-dried, ground, good mixed, sieved through a $2 \mathrm{~mm}$ sieve, kept and analyzed for some physical and chemical properties and its content of available macro- and micronutrients according to the methods described Cottenie et al. (1982); Page et al. (1982).
The obtained data were recorded in Table (1).

Gypsum was added to the soil basis at the rate of 4 ton fed $^{-1}$ to reduce ESP till $15 \%$ (FAO, 1995), the gypsum was used in the form of calcium sulphate $\left(\mathrm{Ca} \mathrm{SO}_{4} .2 \mathrm{H}_{2} \mathrm{O}\right.$ ) after soil preparation and before sowing which was mixed with $0-30 \mathrm{~cm}$ soil surface layer before sowing. Nitrog en in the form of ammonium nitrate $(33.5 \% \mathrm{~N})$, was broadcasted at a rate of 30 as control, 60 and $90 \mathrm{Kg} \mathrm{N} / \mathrm{fed}$, the nitrogen rates were equal doses; the first, being applied after full germination, the second was applied directly after the first cut, and the third dose was added after the second cut. Calcium super phosphate $\left(15.5 \% \mathrm{P}_{2} \mathrm{O}_{5}\right)$ was added at the rate of $150 \mathrm{Kg} \mathrm{fed}^{-1}$ and Potassium sulphate $\left(48 \% \mathrm{~K}_{2} \mathrm{O}\right)$ was added at the rate of $50 \mathrm{Kg}$ fed $^{-1}$ during seed bed preparation.

Table(1) Some physical, chemical and fertility characteristics of the studied soil.

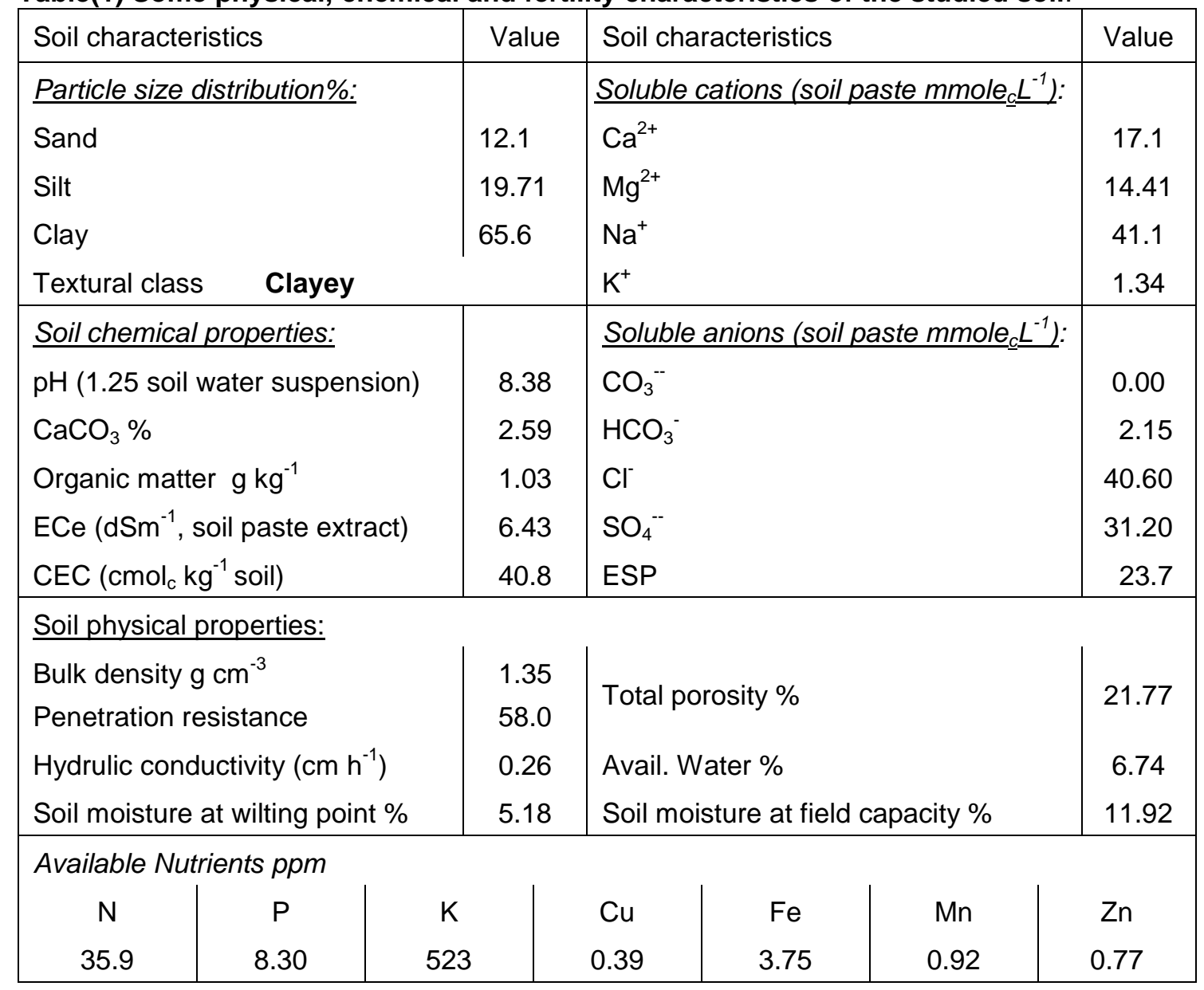


Commercial nitroben was commercial produced by Bio-fertilizer Unit, Agriculture Research Center (ARC), Giza, Egypt, which included free-living bacteria able to fix atmospheric nitrogen. The recommended dose of bio-fertilizer was added with fine clay was added as side-dress near hills. The other agronomic practices were done as recommended. The forage production was estimated over three cuts; the first cut was taken after 50 days from planting which the second was taken after 30 days from the first cut, and the third cut was 30 days after the second cut.

Three factors were arranged in split split - plots with four replications. Two gypsum treatments were applied in the main plots; three nitrogen fertilization levels were assigned in sub-plots and two bio- fertilizer treatments. (with nitroben and without) were assigned to sub- sub plots. Each experimental unit includes 5 ridges, $60 \mathrm{~cm}$ apart and $3.5 \mathrm{~m}$ long, $10.5 \mathrm{~m}^{2}$ in area $(1 / 400$ fed). Seed rate of $20 \mathrm{~kg} \mathrm{fad}^{-1}$ of sudangrass (var. Egyptian Piper) was sown. The planting date was 15th of May for both seasons. Observations were recorded on five guarded plants of each experimental plot and cutting height was $20 \mathrm{~cm}$ above ground.

\section{Studied characters:}

Yield and its component: Plant height was measured in $\mathrm{cm}$ from ground surface to the top of the plant (average of five guarded plants randomly chosen from each plot before every cut). The stem diameter: The stem circumference was measured for each plant and then the stem diameter was calculated using the following formula:

Stem diameter $=$ circumference $/ 2 \pi$. Leaf to stem ratio: Leaves were stripped from the stem. Both leaves and stem were air dried and then weighed to determine the dry weight. The leaf to stem ratio was calculated by dividing the dry weight of leaves by the dry weight of stems. Fresh forage yield (ton $\mathrm{fed}^{-1}$ ) was weighed in $\mathrm{kg} \mathrm{plot}{ }^{-1}$, then converted to ton fed ${ }^{-1}$. Dry plant samples of
$100 \mathrm{~g}$ were dried at $70{ }^{\circ} \mathrm{C}$ to a constant weight and dry matter percentage was estimated. The dry forage yield (ton fed ${ }^{-1}$ ) was calculated by multiplying fresh forage weight (ton $\mathrm{fed}^{-1}$ ) with dry matter percentage.

Chemical composition: dry forage was done following the conventional methods recommended by the Association of the Official Agricultural Chemists (A.O.A.C. 1990) to determine crude protein percentage was determined by micro-Kjeldahl method ( $\mathrm{N}$ content $\times$ 6.25), crude fiber percentage, Total carbohydrates were determined based on the method of phenol sulfuric acid as described by Dubois et al. (1956). Pure glucose was used as standard and the amount of total carbohydrates was expressed as $\mathrm{mg}$ glucose $/ 100 \mathrm{~g}$ dry weight. Gypsum requirement $\left(\mathrm{Mg} \mathrm{fed}^{-1}\right)$ found that (Oster and Frenkel 1980).

At the end of each season, disturbed and undisturbed soil samples were taken from 0 $30 \mathrm{~cm}$. depth and prepared to determine physical and chemical properties according to the standard methods described by Cottenie et al 1982 and Page et al 1982.

Removal sodium efficiency is the percentage of Na-removed from soils at end of the experiment was calculated as follows according to Issam and Sayegh (2007).

$R S E=\left(E S P_{i}-E S P_{f}\right) \backslash E S P_{i} \times 100$

Where:

$\mathrm{ESP}_{\mathrm{i}}=$ exchangeable sodium percentage before the soil amendments application.

$\mathrm{ESP}_{\mathrm{f}}=$ exchangeable sodium percentage after the soil amendments application at the end of the experiment.

Statistical analysis: The obtained data were analyzed statistically according to procedures outlined by Gomez and Gomez (1984). Bartlett's test was done to test the homogeneity of error variances. The test revealed that then was no significant for all traits, thus combined analysis was carried out for all studied traits across the two seasons. Mean comparisons were 
performed using least significant difference (L.S.D.) at $5 \%$ level of probability.

\section{RESULTS AND DISCUSSION I) Sudangrass characters 1) Fresh yield:-}

Results in Table (2) show that the effect of application gypsum, N-level, nitrobein and their interactions on fresh yield. It is clear that fresh yield was significantly increased by increasing $\mathrm{N}$, gypsum and inoculation with nitrobein. The positive impact of gypsum on fresh yield was mainly due to improving the soil physical and chemical properties, preparing the suitable bed for germination and development of plant growth.

Fresh yield was higher in the first cut than in the second or third cut. Maximum fresh yield of 29.5, 27.7 and 26.7 ton fed $^{-1}$ were obtained by applying $90 \mathrm{Kg}$ fed ${ }^{-1} \mathrm{~N}$, gypsum and inoculation with nitrobein, in the first, second and third cut, respectively. In contrast, yield from adding $60 \mathrm{~kg}$ of nitrogen fed $^{-1}$ with bio-fertilizer was no significant compared to applied $90 \mathrm{Kg} \mathrm{fed}^{-1}$ of nitrogen alone without bio-fertilizer inoculation under the same conditions of gypsum application.

The increase in fresh yield may be attributed to the fact that $\mathrm{N}$ - level promote and encourage the formation of more plant growth. Inoculation of sudangrass with nitrobein caused $\mathrm{N}$ - fixation or production of plant growth promoting substances such as indo lactic acids, gibberellins, pyridoxine and others which stimulate plant growth and subsequently affect yield attributes. Similar results were obtained by Alias et al. (2003) on fodder maize and Rashid and lqbal, (2011) on fodder sorghum.

Table (2): Effect of gypsum, nitrogen, nitrobein and their interactions on fresh yield (ton $\mathrm{fed}^{-1}$ ) of sudangrass (combined analysis of two seasons).

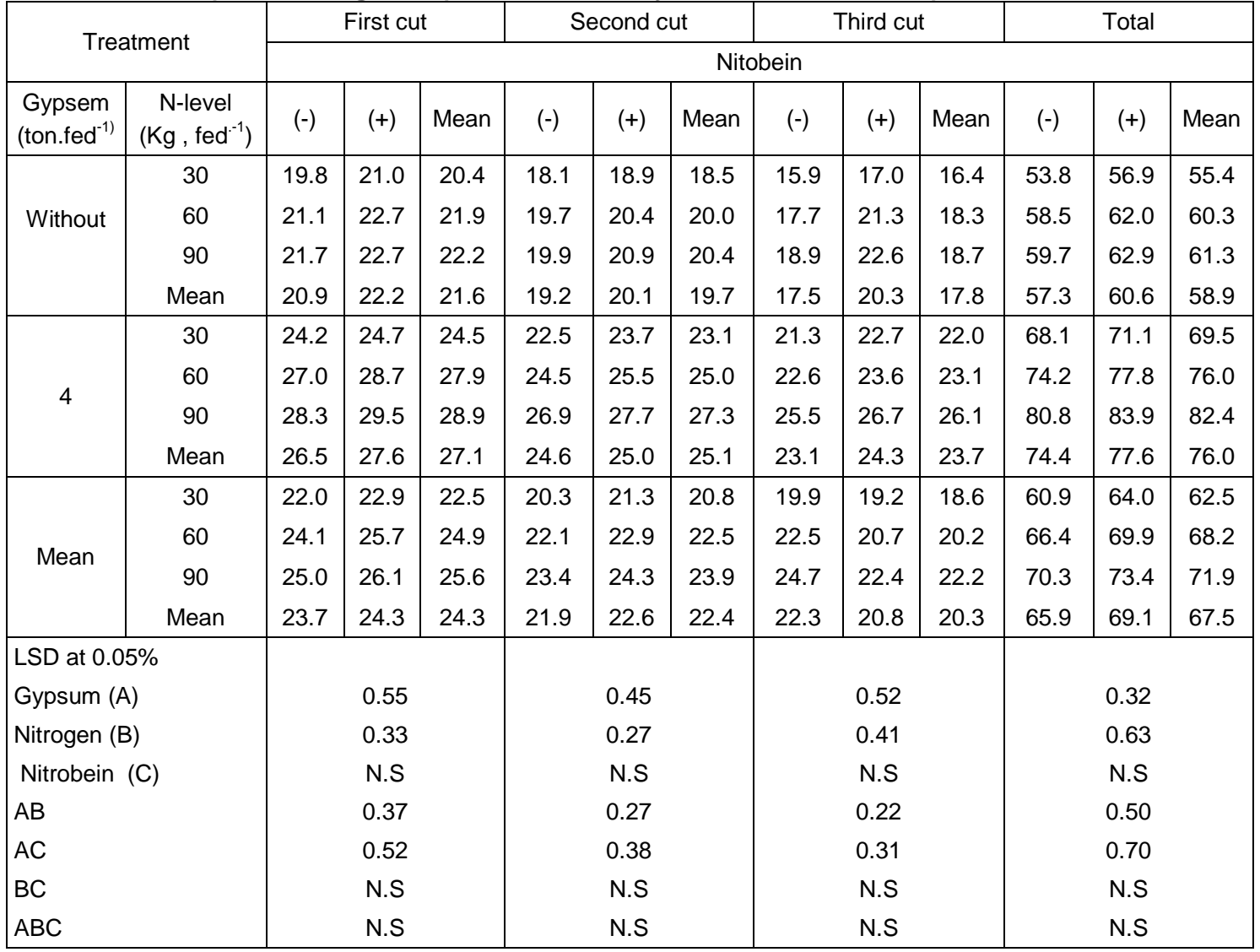

uninocoulation (-), inoculation (+) 


\section{2) Dry yield}

The effect of gypsum, nitrogen-level and bio-fertilizer on dry yield of sudangrass plants is presented in Table (3). There were significant differences among each of gypsum, $\mathrm{N}$ and nitrobein treatments. The interaction between all factor under study indicated that the best dry yield was obtained when plants received $90 \mathrm{Kg}$ nitrogen fed $^{-1}$, and 4 ton gypsum fed ${ }^{-1}$ with inoculation treatment .The trend of dry yield was similarly as it was recorded for fresh yield. The maximum dry matter values of $12.1,11.1$ and 10.5 ton fed $^{-1}$ were obtained by applying the highest rate of $\mathrm{N}$ and gypsum with inoculation, followed by 11.6 , 10.3 and 10.1 ton $^{-1}{ }^{-1}$ without inoculation for the three cuts, respectively. It has been found that the use of $60 \mathrm{Kg} \mathrm{N}^{-1}{ }^{-1}$ of and bio- fertilization or using of $90 \mathrm{Kg} \mathrm{N}_{\text {fed }}{ }^{-1}$ alone under the same conditions of applied gypsum gave no- significant dry yield.

\section{3) Plant height}

The effect of gypsum, nitrogen- level and bio-fertilizer on plant height of sudangrass is presented in Table (4). Results indicated that there were significant differences due to using the three levels of nitrogen fertilizer. Plant height increased due to increasing nitrogen level up to $90 \mathrm{Kg}_{\text {fed }}{ }^{-1}$ nitrogen. Also, plants received 4 ton gypsum fed${ }^{1}$ were taller than those of control treatment with or without bio- fertilization. There were significant differences among the interactions between all factors. Adding level $90 \mathrm{Kg} \mathrm{N}$ fed $^{-1}$ gypsum with nitrobein inoculation gave the tallest sudangrass plants compared to uninoculation (without bio-fertilizer). It has been found that the use of $60 \mathrm{Kg} \mathrm{fed}{ }^{-1}$ of $\mathrm{N}$ and bio- fertilization produced similar results when using $90 \mathrm{Kg} \mathrm{N}$ fed ${ }^{-1}$ alone without bio-fertilization under the same conditions of gypsum.

Table (3): Effect of gypsum, nitrogen, nitrobein and their interactions on dry yield (ton $\mathrm{fed}^{-1}$ ) of sudangrass (combined analysis of two seasons).

\begin{tabular}{|c|c|c|c|c|c|c|c|c|c|c|c|c|c|}
\hline \multirow{2}{*}{\multicolumn{2}{|c|}{ Treatment }} & \multicolumn{3}{|c|}{ First cut } & \multicolumn{3}{|c|}{ Second cut } & \multicolumn{3}{|c|}{ Third cut } & \multicolumn{3}{|c|}{ Total } \\
\hline & & \multicolumn{12}{|c|}{ Nitrobein } \\
\hline $\begin{array}{l}\text { Gypsem } \\
\text { (ton.fed }^{-1)}\end{array}$ & $\begin{array}{c}\text { N-level } \\
\left(\mathrm{Kg} \text { fed }^{-1}\right)\end{array}$ & $(-)$ & $(+)$ & Mean & $(-)$ & $(+)$ & Mean & $(-)$ & $(+)$ & Mean & $(-)$ & $(+)$ & Mean \\
\hline \multirow{4}{*}{ without } & 30 & 8.37 & 8.27 & 8.32 & 7.40 & 6.97 & 7.19 & 5.80 & 6.20 & 6.00 & 21.6 & 21.4 & 21.5 \\
\hline & 60 & 9.21 & 9.53 & 9.37 & 8.10 & 8.70 & 8.40 & 6.03 & 7.57 & 6.80 & 23.3 & 25.8 & 24.6 \\
\hline & 90 & 9.51 & 9.90 & 9.71 & 8.67 & 9.20 & 8.94 & 6.67 & 7.93 & 7.30 & 24.8 & 27.0 & 25.9 \\
\hline & Mean & 9.03 & 9.23 & 9.13 & 8.06 & 8.29 & 8.18 & 6.17 & 7.23 & 6.70 & 23.3 & 24.7 & 24.0 \\
\hline \multirow{4}{*}{4} & 30 & 6.27 & 9.10 & 7.68 & 7.70 & 8.50 & 8.10 & 7.33 & 7.80 & 7.57 & 21.3 & 25.4 & 23.4 \\
\hline & 60 & 10.4 & 10.8 & 10.6 & 9.70 & 10.4 & 10.1 & 7.8 & 8.9 & 8.35 & 27.9 & 30.0 & 29.0 \\
\hline & 90 & 11.6 & 12.1 & 11.8 & 10.3 & 11.1 & 10.7 & 10.1 & 10.5 & 10.3 & 32.0 & 33.7 & 32.9 \\
\hline & mean & 9.43 & 10.7 & 10.07 & 9.24 & 9.98 & 9.61 & 8.40 & 9.07 & 8.74 & 27.1 & 29.7 & 28.4 \\
\hline \multirow{4}{*}{ Mean } & 30 & 7.32 & 8.69 & 8.01 & 7.55 & 7.74 & 7.65 & 6.57 & 7.0 & 6.79 & 21.5 & 23.4 & 22.5 \\
\hline & 60 & 9.81 & 10.17 & 9.99 & 8.90 & 9.55 & 9.25 & 6.92 & 8.24 & 7.58 & 25.6 & 27.9 & 26.8 \\
\hline & 90 & 10.56 & 11.0 & 10.78 & 9.49 & 10.15 & 9.82 & 8.39 & 9.21 & 8.80 & 28.4 & 30.4 & 29.4 \\
\hline & mean & 9.13 & 9.97 & 9.60 & 8.65 & 9.14 & 8.90 & 7.29 & 8.15 & 7.72 & 25.2 & 27.2 & 26.2 \\
\hline \multicolumn{14}{|c|}{ LSD at $0.05 \%$} \\
\hline \multicolumn{2}{|c|}{ Gypsum (A) } & \multicolumn{3}{|c|}{0.14} & \multicolumn{3}{|c|}{0.06} & \multicolumn{3}{|c|}{0.25} & \multicolumn{3}{|c|}{0.67} \\
\hline \multicolumn{2}{|c|}{ Nitrogen (B) } & \multicolumn{3}{|c|}{0.11} & \multicolumn{3}{|c|}{0.24} & \multicolumn{3}{|c|}{0.08} & \multicolumn{3}{|c|}{0.93} \\
\hline \multicolumn{2}{|c|}{ Nitrobein (C) } & \multicolumn{3}{|c|}{0.15} & \multicolumn{3}{|c|}{ N.S } & \multicolumn{3}{|c|}{0.11} & \multicolumn{3}{|c|}{ N.S } \\
\hline \multicolumn{2}{|c|}{$\mathrm{AB}$} & \multicolumn{3}{|c|}{0.22} & \multicolumn{3}{|c|}{0.18} & \multicolumn{3}{|c|}{0.30} & \multicolumn{3}{|c|}{0.81} \\
\hline \multicolumn{2}{|c|}{$A C$} & & 0.31 & & & 0.26 & & & 0.42 & & & 1.14 & \\
\hline & C & & 0.31 & & & N.S & & & N.S & & & N.S & \\
\hline & $3 C$ & & 0.43 & & & 0.36 & & & N.S & & & 1.61 & \\
\hline
\end{tabular}

uninocoulation (-), inoculation (+) 


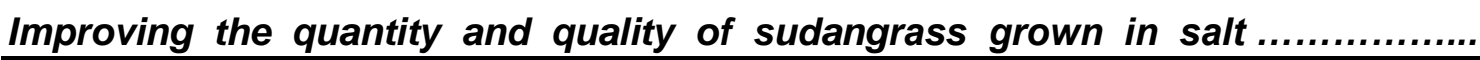

Table (4): Effect of gypsum, nitrogen, nitrobein and their interactions on plant height $(\mathrm{cm})$ of sudangrass (combined analysis of two seasons).

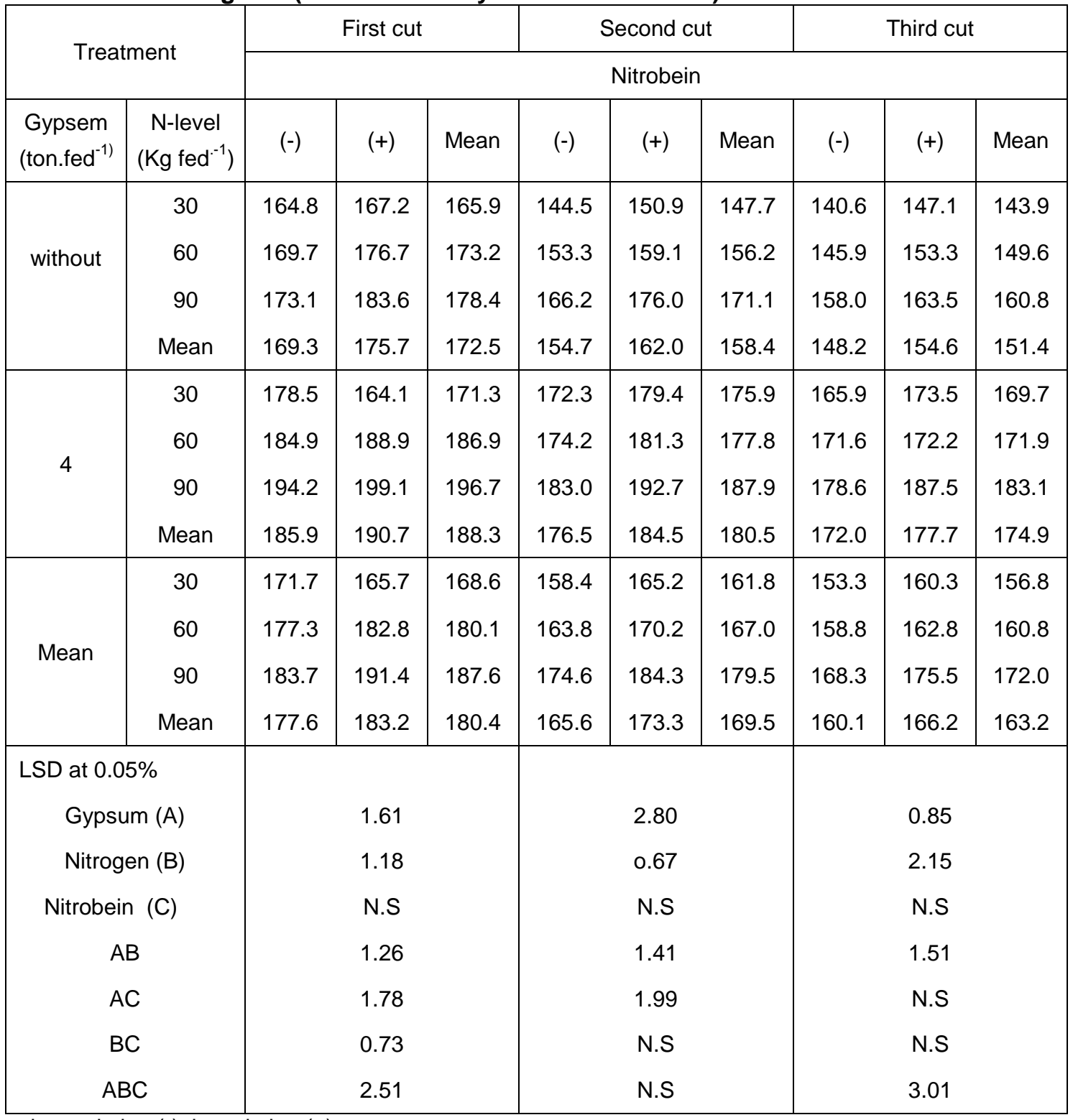

uninocoulation (-), inoculation (+)

The beneficial effects of nitrogen on stimulating the meristematic activity for producing more tissues and organs where $\mathrm{N}$ play major roles in structural proteins and other several macromolecules related with growth plants (Marschner, 1995). The improvement when used bio-fertilization with Sudan grass plant led to increase in plant growth was presented by many workers such as; Carletti et al., (1996) and Lazarovls and Nowak (1997). Also, the improving in plant growth associated with increase in gypsum, to improving the soil physical and chemical properties, preparing the suitable bed for germination and development of plant growth that reflect on yield production.

\section{4) Stem diameter and leaf/stem ratio:. \\ Results in Table (5 and 6) show the} effect of $\mathrm{N}$-level, gypsum and inoculation with nitrobein and their interactions on stem 
diameter and leaf/stem ratio, respectively. It is clear that stem diameter and leaflstem ratio was significantly increased by increasing $\mathrm{N}$, adding gypsum and nitrobein. The positive impacts of Gypsum on stem diameter and leaflstem ratio was mainly due to improving the soil physical and chemical properties, preparing the suitable bed for germination and development plant growth. Stem diameter and leaf/stem ratio was higher in the first cut than the second or third cut. Maximum Stem diameter and leaflstem ratio were obtained when applying $90 \mathrm{Kg} \mathrm{N}$ fed $^{-1}$ and gypsum with inoculation nitrobein, In contrast, it was found that the use of 60 $\mathrm{Kg} \mathrm{N}$ fed. $^{-1}$ with bio-fertilizer gave no significant results compared to using $90 \mathrm{Kg}$ $\mathrm{N}$ fed $^{-1}$ alone without bio- fertilization. These results are in hormony with those obtained by Samia et al. (2010) and Khalid et al., (2010) found that progressive increase in nitrogen level, stem diameter was also increased.

Table (5): Effect of gypsum, nitrogen, nitrobein and their interactions on leaf/stem ratio (\%) of sudangrass (combined analysis of two seasons).

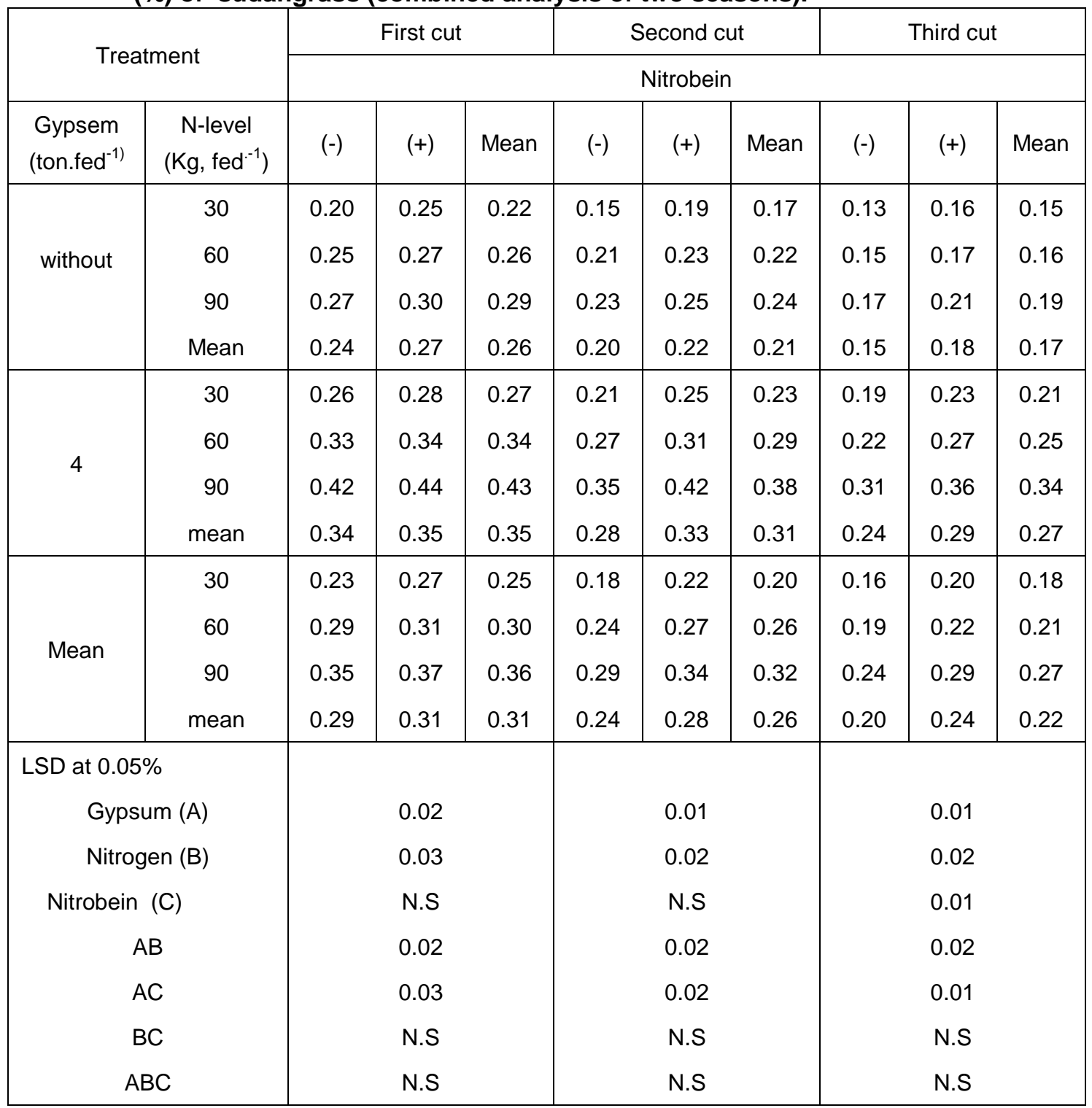

uninocoulation (-), inoculation (+) 


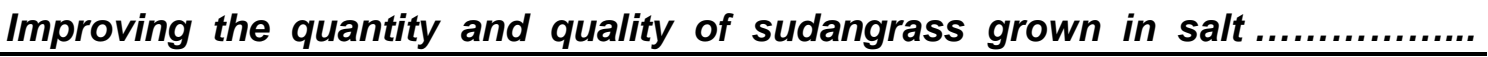

Table (6): Effect of gypsum, nitrogen, nitrobein and their interactions on stem diameter (cm) of sudangrass (combined analysis of two seasons).

\begin{tabular}{|c|c|c|c|c|c|c|c|c|c|c|}
\hline \multirow{2}{*}{\multicolumn{2}{|c|}{ Treatment }} & \multicolumn{3}{|c|}{ First cut } & \multicolumn{3}{|c|}{ Second cut } & \multicolumn{3}{|c|}{ Third cut } \\
\hline & & \multicolumn{9}{|c|}{ Nitrobein } \\
\hline $\begin{array}{l}\text { Gypsem } \\
\text { (ton.fed }^{-1)}\end{array}$ & $\begin{array}{c}\text { N-level } \\
\left(\text { Kg fed }^{-1}\right)\end{array}$ & $(-)$ & $(+)$ & Mean & $(-)$ & $(+)$ & Mean & $(-)$ & $(+)$ & Mean \\
\hline \multirow{4}{*}{ without } & 30 & 1.30 & 1.35 & 1.33 & 1.17 & 1.23 & 1.20 & 1.09 & 1.18 & 1.14 \\
\hline & 60 & 1.30 & 1.44 & 1.37 & 1.29 & 1.37 & 1.33 & 1.22 & 1.29 & 1.26 \\
\hline & 90 & 1.45 & 1.52 & 1.49 & 1.38 & 1.43 & 1.41 & 1.28 & 1.26 & 1.29 \\
\hline & Mean & 1.37 & 1.44 & 1.41 & 1.28 & 1.34 & 1.31 & 1.20 & 1.23 & 1.19 \\
\hline \multirow{4}{*}{4} & 30 & 1.59 & 1.57 & 1.58 & 1.45 & 1.53 & 1.49 & 1.39 & 1.41 & 1.42 \\
\hline & 60 & 1.62 & 1.72 & 1.67 & 1.51 & 1.62 & 1.57 & 1.45 & 1.46 & 1.47 \\
\hline & 90 & 1.78 & 1.85 & 1.82 & 1.65 & 1.74 & 1.70 & 1.59 & 1.61 & 1.62 \\
\hline & mean & 1.64 & 1.72 & 1.69 & 1.54 & 1.63 & 1.58 & 1.47 & 1.47 & 1.50 \\
\hline \multirow{4}{*}{ Mean } & 30 & 1.45 & 1.46 & 1.46 & 1.31 & 1.38 & 1.35 & 1.24 & 1.30 & 1.28 \\
\hline & 60 & 1.46 & 1.58 & 1.52 & 1.40 & 1.50 & 1.45 & 1.34 & 1.38 & 1.36 \\
\hline & 90 & 1.62 & 1.69 & 1.66 & 1.52 & 1.59 & 1.56 & 1.44 & 1.47 & 1.45 \\
\hline & mean & 1.51 & 1.58 & 1.55 & 1.41 & 1.49 & 1.45 & 1.34 & 1.38 & 1.36 \\
\hline \multicolumn{11}{|c|}{ LSD at $0.05 \%$} \\
\hline \multicolumn{2}{|c|}{ Gypsum (A) } & \multicolumn{3}{|c|}{0.01} & \multicolumn{3}{|c|}{0.04} & \multicolumn{3}{|c|}{0.01} \\
\hline \multicolumn{2}{|c|}{ Nitrogen (B) } & \multicolumn{3}{|c|}{0.01} & \multicolumn{3}{|c|}{0.01} & \multicolumn{3}{|c|}{0.04} \\
\hline \multicolumn{2}{|c|}{ Nitrobein $(\mathrm{C})$} & \multicolumn{3}{|c|}{0.01} & \multicolumn{3}{|c|}{ N.S } & \multicolumn{3}{|c|}{ N.S } \\
\hline \multicolumn{2}{|c|}{$\mathrm{AB}$} & \multicolumn{3}{|c|}{0.01} & \multicolumn{3}{|c|}{0.02} & \multicolumn{3}{|c|}{0.01} \\
\hline \multicolumn{2}{|c|}{$A C$} & \multicolumn{3}{|c|}{ N.S } & \multicolumn{3}{|c|}{0.03} & \multicolumn{3}{|c|}{0.02} \\
\hline \multicolumn{2}{|c|}{$\mathrm{BC}$} & \multicolumn{3}{|c|}{ N.S } & \multicolumn{3}{|c|}{ N.S } & & N.S & \\
\hline & $3 \mathrm{C}$ & & N.S & & & N.S & & & N.S & \\
\hline
\end{tabular}

uninocoulation (-), inoculation (+)

\section{5) Nitrogen content (\%):-}

Results in Table (7) results show that the application of $\mathrm{N}$ had significant effect on leaf $\mathrm{N}$ content. Application $90 \mathrm{Kg} \mathrm{N}$ fed $^{-1}$ and gypsum with inoculation of nitrobein gave the highest nitrogen contents of $1.87,1.83$ and $1.79 \%$ in the first, second and third cuts, respectively. It has been found that no significant effect on $\mathrm{N}$ content between the use of $60 \mathrm{Kg} \mathrm{N}$ fed $^{-1}$ with bio- fertilization and when using $90 \mathrm{Kg} \mathrm{N}^{-1} \mathrm{fed}^{-1}$ alone without bio-fertilization. The interaction of nitrogen level, gypsum and inoculation nitrobein had a significant effect on nitrogen content. This may be due to the role of bio-fertilizers in growth roots and high response of sudangrass to nitrogen application. Similar results were obtained by (Ashiono et al., 2005).

6) Crude protein of plants (\%):.

The data presented in Table (8), show that the effect of $\mathrm{N}$ - levels and application gypsum with inoculation on crude protein content was highly significant. Maximum crude protein content was $11.7,11.5$ and $11.2 \%$ at application $90 \mathrm{Kg} \mathrm{N}$ fed $^{-1}$ and gypsum with inoculation nitrobein in the first, second and third cuts, respectively. It has been found that the use of $60 \mathrm{Kg} \mathrm{N}$ fed ${ }^{-1}$ with bio- fertilization gave the similar results when using $90 \mathrm{Kg} \mathrm{N}$ fed $^{-1}$ without biofertilization under the same conditions when added gypsum. 
The increases of crude protein content due to the addition of $\mathrm{N}$ may be attributed to the beneficial effect of $\mathrm{N}$ on protein formation. Bio-fertilization and gypsum application may be enhanced $\mathrm{N}$ fixation to be utilized by plants and ultimately increased the protein content. In this respect, Amandeep (2012) suggested that the increase in crude protein with increasing the $\mathrm{N}$ application was due to increased absorption of $N$. Since $N$ is the main constituent of amino acids, it ultimately increased crude protein contents of plants. These results are in agreement with those mentioned by Afzal et al. (2012).

Table (7): Effect of gypsum, nitrogen, nitrobein and their interactions on $\mathbf{N}$ content (\%) of sudangrass (combined analysis of two seasons).

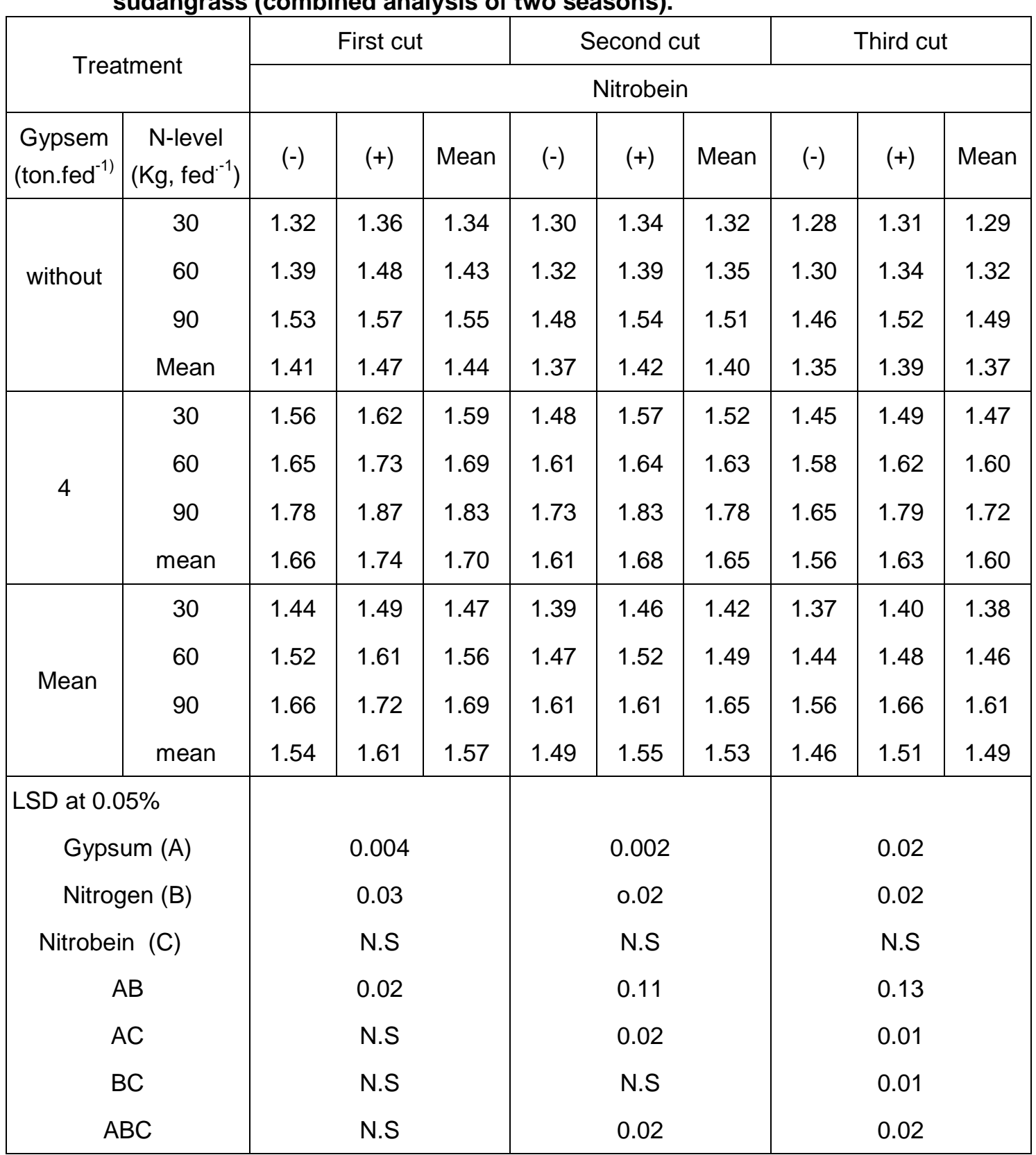

uninocoulation (-), inoculation (+) 


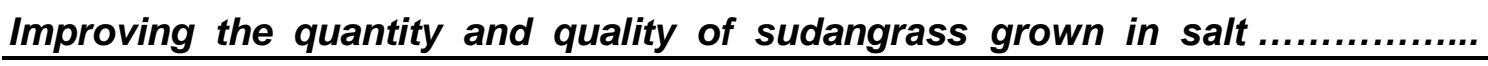

Table (8): Effect of gypsum, nitrogen, nitrobein and their interactions on crude protein content (\%) of sudangrass (combined analysis of two seasons).

\begin{tabular}{|c|c|c|c|c|c|c|c|c|c|c|}
\hline \multirow{2}{*}{\multicolumn{2}{|c|}{ Treatment }} & \multicolumn{3}{|c|}{ First cut } & \multicolumn{3}{|c|}{ Second cut } & \multicolumn{3}{|c|}{ Third cut } \\
\hline & & \multicolumn{9}{|c|}{ Nitrobein } \\
\hline $\begin{array}{l}\text { Gypsem } \\
\text { (ton.fed }^{-1)}\end{array}$ & $\begin{array}{c}\text { N-level } \\
\left(\mathrm{Kg}^{\text {fed }}{ }^{-1}\right)\end{array}$ & $(-)$ & $(+)$ & Mean & $(-)$ & $(+)$ & Mean & $(-)$ & $(+)$ & Mean \\
\hline \multirow{4}{*}{ without } & 30 & 8.2 & 8.48 & 8.34 & 8.10 & 8.36 & 8.23 & 7.98 & 8.18 & 8.08 \\
\hline & 60 & 8.7 & 9.23 & 8.96 & 8.23 & 8.68 & 8.46 & 8.12 & 8.36 & 8.24 \\
\hline & 90 & 9.6 & 9.83 & 9.71 & 9.22 & 9.63 & 9.43 & 9.12 & 9.47 & 9.30 \\
\hline & Mean & 8.8 & 9.18 & 8.99 & 8.52 & 8.89 & 8.71 & 8.41 & 8.67 & 8.54 \\
\hline \multirow{4}{*}{4} & 30 & 9.7 & 10.1 & 9.90 & 9.23 & 9.78 & 9.51 & 9.04 & 9.30 & 9.17 \\
\hline & 60 & 10.3 & 10.8 & 10.5 & 10.1 & 10.3 & 10.2 & 9.86 & 10.1 & 9.98 \\
\hline & 90 & 11.1 & 11.7 & 11.4 & 10.8 & 11.5 & 11.2 & 10.3 & 11.2 & 10.8 \\
\hline & mean & 10.4 & 10.9 & 10.6 & 10.1 & 10.5 & 10.3 & 9.74 & 10.2 & 9.97 \\
\hline \multirow{4}{*}{ Mean } & 30 & 8.95 & 9.29 & 9.12 & 8.67 & 9.07 & 8.87 & 8.51 & 8.74 & 8.63 \\
\hline & 60 & 10.0 & 10.0 & 9.76 & 9.17 & 9.49 & 9.33 & 8.99 & 9.23 & 9.11 \\
\hline & 90 & 10.4 & 10.8 & 10.6 & 10.0 & 10.6 & 10.3 & 9.71 & 10.3 & 10.1 \\
\hline & mean & 9.60 & 10.0 & 9.80 & 9.31 & 9.70 & 9.51 & 9.08 & 9.44 & 9.26 \\
\hline \multicolumn{11}{|c|}{ LSD at $0.05 \%$} \\
\hline \multicolumn{2}{|c|}{ Gypsum (A) } & \multicolumn{3}{|c|}{0.03} & \multicolumn{3}{|c|}{0.10} & \multicolumn{3}{|c|}{0.09} \\
\hline \multicolumn{2}{|c|}{ Nitrogen (B) } & \multicolumn{3}{|c|}{0.17} & \multicolumn{3}{|c|}{0.11} & \multicolumn{3}{|c|}{0.09} \\
\hline \multicolumn{2}{|c|}{ Nitrobein $(\mathrm{C})$} & \multicolumn{3}{|c|}{ N.S } & \multicolumn{3}{|c|}{ N.S } & \multicolumn{3}{|c|}{ N.S } \\
\hline \multicolumn{2}{|c|}{$A B$} & \multicolumn{3}{|c|}{0.14} & \multicolumn{3}{|c|}{0.07} & \multicolumn{3}{|c|}{0.06} \\
\hline \multicolumn{2}{|c|}{ AC } & \multicolumn{3}{|c|}{ N.S } & \multicolumn{3}{|c|}{0.10} & \multicolumn{3}{|c|}{0.08} \\
\hline \multicolumn{2}{|c|}{$\mathrm{BC}$} & \multicolumn{3}{|c|}{ N.S } & \multicolumn{3}{|c|}{0.10} & & 0.08 & \\
\hline & & & N.S & & & 0.14 & & & 0.11 & \\
\hline
\end{tabular}

uninocoulation (-), inoculation (+)

\section{7) Crude fiber of plants:-}

Data in Table (9) show that the increase in crude fiber content of sudangrasses was observed when plants received $\mathrm{N}$ and biofertilizer. However, application of $\mathrm{N}$ levels and bio -fertilizer without gypsum caused a significant decrease in crude fiber than applied gypsum. The maximum crude fiber content was $31.9,30.3$ and $29.7 \%$ by inoculation at the rate of $90 \mathrm{Kg} \mathrm{N}$ fed ${ }^{-1}$ under gypsum treated in the first, second and third cuts, respectively. It has been found that the use of $60 \mathrm{Kg} \mathrm{N}^{-1}$ and bio- fertilization gave the same results when using $90 \mathrm{Kg} \mathrm{N}$ $\mathrm{fed}^{-1}$ alone without bio-fertilization under gypsum treatment. In this respect, Ayub et al., (2002) reported that the crude fiber content was significantly influenced by the application of $\mathrm{N}$ and gypsum. Also, Amandeep (2012) indicted that the application of $\mathrm{N}$ had depressing effect on crude fiber content because it an increased leaf weight and wider leaf-stem ratio which might had decreased the crude fiber content in sorghum.

\section{8) Total Carbohydrates content plants (\%)}

Results in Table (10) show that the effect of application gypsum, N-fertilizer and 
nitrobein on sudangrass carbohydrate content. The maximum carbohydrate values $(55.8,54.6$, and $53.2 \%)$ were obtained plant treated with gypsum, $90 \mathrm{Kg} \mathrm{N}$ fed $^{-1}$ and nitrobein. While, the minimum values $(42.3$, 40.9 , and $39.9 \%$ ) were obtained by the lowest rate of $\mathrm{N}$ only in the first, second and third cuts, respectively. It has been found that the use of $60 \mathrm{Kg} \mathrm{N}^{-1} \mathrm{fed}^{-1}$ and biofertilizer was no significant with using $90 \mathrm{~kg}$ $\mathrm{N}$ fed $^{-1}$ alone. Almodares et al., (2009) showed that the carbohydrate content was decreased as the level of nitrogen increased.

\section{II) Soil characters: \\ 1) Soil nitrogen content}

Data in Table (11) show that the application of $\mathrm{N}$ had significant effect on soil $\mathrm{N}$ content which was higher at the first cut compared to the second or third cut. The maximum soil $\mathrm{N}$ content were $62.7,58.9$, $55.6 \mathrm{mgkg}^{-1}$ soil by applied $90 \mathrm{Kg} \mathrm{N}$, fed ${ }^{-1}$. While, the minimum values were $32.4,30.6$, $28.2 \mathrm{mgkg}^{-1}$ soil by applied $30 \mathrm{Kg} \mathrm{N}$, fed ${ }^{1}$ in the first, second and third cuts, respectively. Similar results were obtained by (Hassan, 2003).

Table (9): Effect of gypsum, nitrogen, nitrobein and their interactions on crude fiber content (\%) of sudangrass (combined analysis of two seasons).

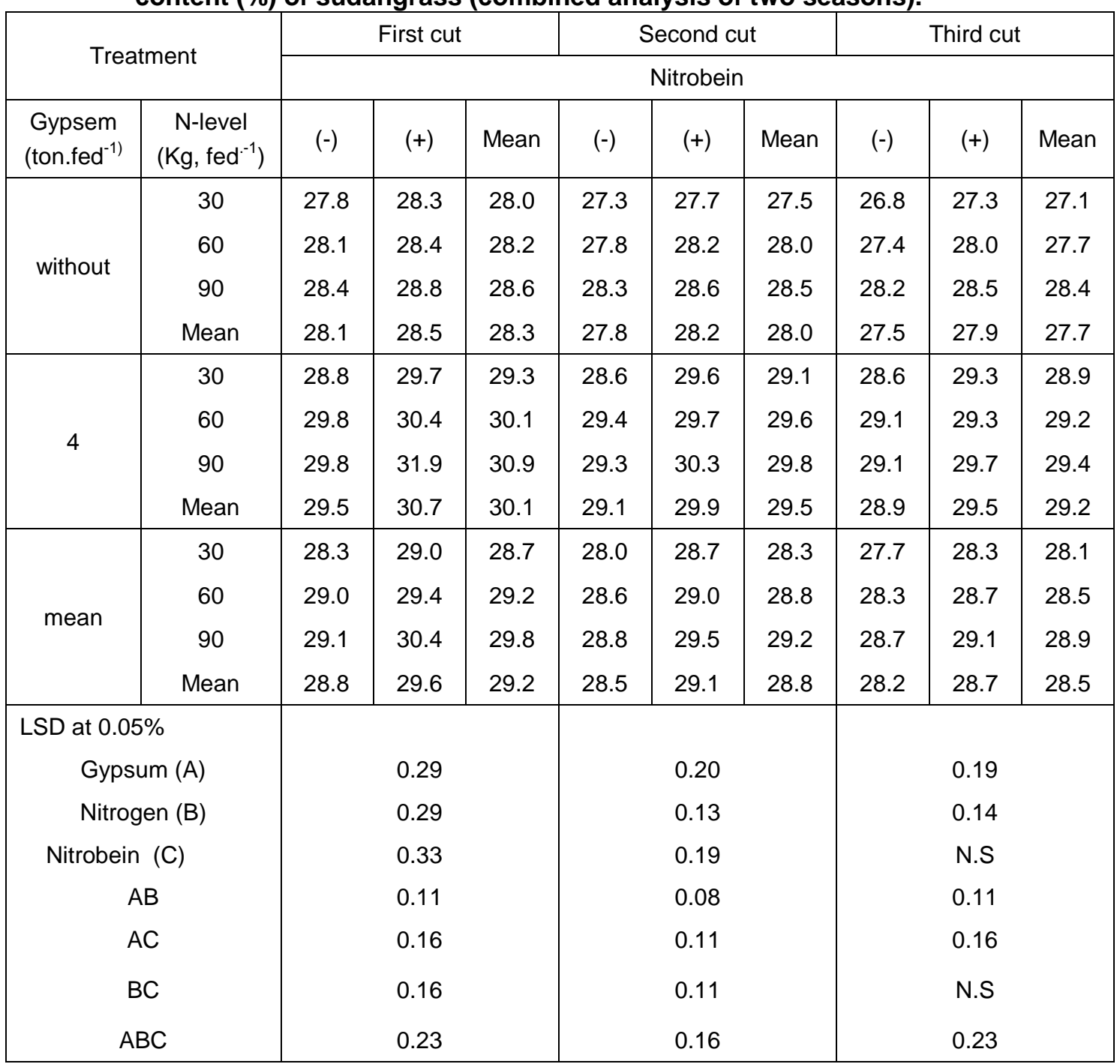

uninocoulation (-), inoculation (+) 


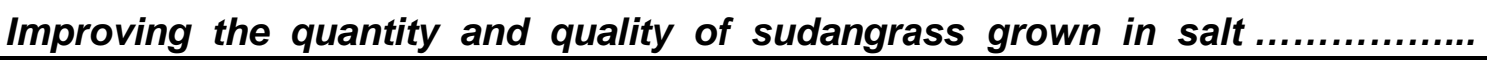

Table (10): Effect of gypsum, nitrogen, nitrobein and their interactions on carbohydrates (\%) of sudangrass (combined analysis of two seasons).

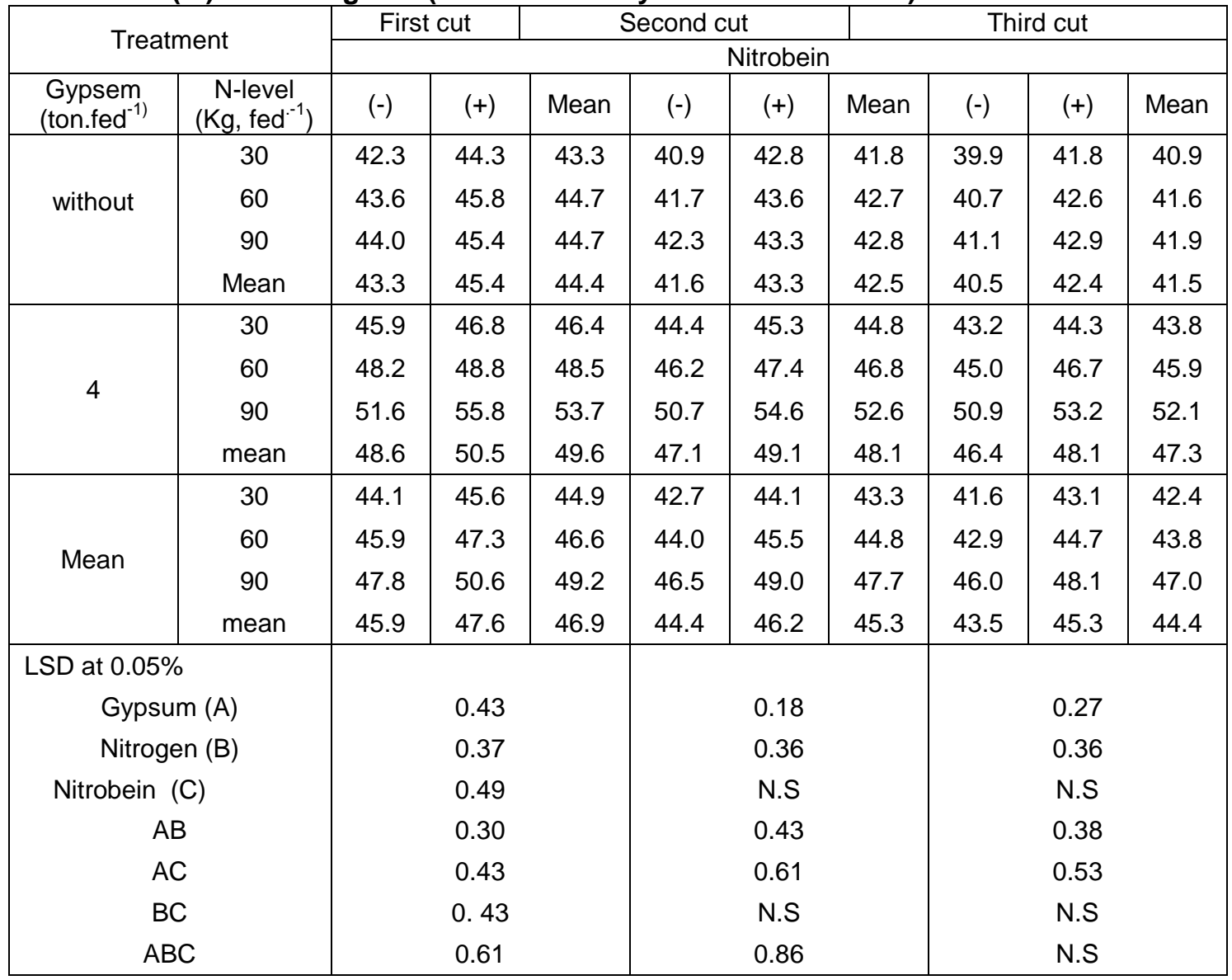

uninocoulation (-), inoculation (+)

Table (11): Soil nitrogen content as influenced by $\mathrm{N}$ application

\begin{tabular}{|c|c|c|c|c|}
\hline \multirow{2}{*}{$\mathrm{N}$ - levels $\left(\mathrm{kg} \mathrm{fed}^{-1}\right)$} & \multicolumn{4}{|c|}{ Soil N $\left(\mathrm{mg} \mathrm{kg}^{-1)}\right.$} \\
\cline { 2 - 5 } & $1^{\text {st }}$ Cut & $2^{\text {nd }}$ Cut & $3^{\text {rd }}$ Cut & Mean \\
\hline 30 & 32.4 & 30.6 & 28.2 & 30.4 \\
\hline 60 & 46.5 & 42.8 & 39.3 & 42.9 \\
\hline 90 & 62.7 & 58.9 & 55.6 & 38.2 \\
\hline Mean & 47.2 & 44.1 & 41.0 & 37.16 \\
\hline
\end{tabular}

\section{2) Soil salinity (ECe):,}

The data in Table (12) indicated that soil ECe values were decreased from 4.5 and 4.4 to 3.2 and $2.9 \mathrm{dSm}^{-1}$ by applying gypsum for both seasons, respectively. In this respect, gypsum application was the most effective in decreasing soil salinity. This could be attributed to the presence of gypsum as soil amendments has high content of $\mathrm{CaSO}_{4}$ and can be used as a source of $\mathrm{Ca}^{++}$which increase exchangeable and soluble calcium. As well as, the surface applied water would pass through the surface applied amendment and infiltrate the top layers allowing exchange process between $\mathrm{Ca}^{++}$and $\mathrm{Na}^{+}$(El-Sharawy et al., 2008). The effects of application gypsum on soluble ions of saline sodic soil at the two seasons are also presented in Table (14). It is obvious that gypsum markedly increased 
the concentration of $\mathrm{Ca}^{++}$, while it sharply decreased $\mathrm{Na}^{+}$concentration. Similar results were obtained by (El-Masry, 2001). The beneficial effects of application gypsum on physical characteristics may be increased the movement of ions in the drainage water. $\mathrm{Na}^{+}$was the dominant cations to be removed from the soil.

\section{3) Soil PH}

Soil $\mathrm{pH}$ has a considerable impact on controlling the plant nutrients, particularly the availability of micronutrients (Naidu and Rengasamy, 1993). In this study, the obtained data (Table12) revealed differences between the soil treatments. Application of gypsum had the ameliorative potential to decrease the $\mathrm{pH}$ value of soil. This could be attributed to the soil application of gypsum produces $\mathrm{SO}_{4}{ }^{-}$tons which converted to $\mathrm{H}_{2} \mathrm{SO}_{4}$ that interact with $\mathrm{Ca}^{++}$ions and decrease the $\mathrm{pH}$ value and both soluble and exchangeable $\mathrm{Na}^{+}$in the soil (El-Masry, 2001).

\section{4) Soil sodicity (ESP)}

The sodification phenomenon constitutes highly complicated problem in the studied clay soil, which constricts its productivity. Data in Table (12) show that gradual obvious decline in ESP value with increasing during the experimental time, where its value reduced below the safe limit $(<15 \%)$ after second seasons. Data showed that the exchangeable sodium percentage (ESP) before application amendments tend to be high in the soil $(20.7 \%$ for first season). While, after application gypsum, ESP decreased about of $15 \%$ and $27.5 \%$ for the first and second season, respectively. This could be attributed to the dominance of soluble calcium on the exchange complex which decreased encourage of both soluble and exchangeable sodium hence decreasing the ESP values. These results are in agreement with those of (Mansour et al., 2014 and Abd El-Hamid et al., 2011).

\section{5) Soil physical properties a) Soil bulk density (B.D.)}

Soil bulk density is the main soil character that must be taken into consideration when improving soil physical properties.

Bulk density was mostly affected by soluble salts content as a result of applied gypsum. Data in Table (12) indicated that the soil bulk density was improved as a result of application gypsum. The value of bulk density was decreased from 1.53 to $1.36 \mathrm{gm} \mathrm{cm}^{-3}$ in the first season and from 1.47 to 1.31 in the second season. These results may be attributed to the decomposition amendments and increasing exchangeable calcium which enhance aggregation process and consequently increase apparent soil bulk density volume and decrease soil bulk density (Abd ElHamid, 2011).

Table (12): Effect of gypsum on some chemical and physical properties of the soil under investigation

\begin{tabular}{|c|c|c|c|c|c|c|c|c|c|c|c|c|c|}
\hline \multirow{3}{*}{$\begin{array}{l}\text { Gypsum } \\
\text { (ton fed }^{-1} \text { ) }\end{array}$} & \multirow{3}{*}{$\mathrm{pH}$} & \multirow{3}{*}{$\begin{array}{c}E c \\
\left(\mathrm{dSm}^{-1}\right)\end{array}$} & \multicolumn{7}{|c|}{ Soluble ions in soil paste extract(meq. $\left.\mathrm{L}^{-1}.\right)$} & \multirow{3}{*}{$\begin{array}{c}\text { B.D } \\
\mathrm{gm} \mathrm{cm}^{-3} \text { ) }\end{array}$} & \multirow{3}{*}{$\begin{array}{c}\mathrm{K} \\
\left(\mathrm{cm} \mathrm{h}^{-1}\right)\end{array}$} & \multirow{3}{*}{$\begin{array}{l}\text { Penetration } \\
\text { resistance } \\
\left(\text { Mg. } \mathrm{m}^{-223}\right)\end{array}$} & \multirow{3}{*}{$\begin{array}{c}\text { E.S.P } \\
(\%)\end{array}$} \\
\hline & & & \multicolumn{3}{|c|}{ Anions } & \multicolumn{4}{|c|}{ Cations } & & & & \\
\hline & & & $\mathrm{HCO}_{3}{ }^{-}$ & $\mathrm{Cl}^{-}$ & $\mathrm{SO}_{4}^{-}$ & $\mathrm{Ca}^{++}$ & $\mathrm{Mg}^{++}$ & $\mathrm{Na}^{+}$ & $\mathrm{K}^{+}$ & & & & \\
\hline \multicolumn{14}{|c|}{2014 Season } \\
\hline without & 8.6 & 4.5 & 3.0 & 28.1 & 18.9 & 9.6 & 6.5 & 33.3 & 0.6 & 1.53 & 0.26 & 58.0 & 20.7 \\
\hline 4 & 8.3 & 3.2 & 2.7 & 11.5 & 17.8 & 17.4 & 6.7 & 7.2 & 0.7 & 1.36 & 0.87 & 45.6 & 17.8 \\
\hline \multicolumn{14}{|c|}{2015 Season } \\
\hline without & 8.5 & 4.4 & 3.5 & 27.9 & 18.6 & 9,2 & 6.7 & 33.5 & 0.6 & 1.47 & 0.43 & 51.0 & 20.6 \\
\hline 4 & 8.2 & 2.9 & 1.7 & 7.3 & 20.0 & 14.6 & 8.5 & 5.0 & 0.9 & 1.31 & 198 & 42.7 & 15.0 \\
\hline
\end{tabular}




\section{b) Soil hydraulic conductivity (Ks)}

The distinguishing characteristics of slowly permeable saline sodic and sodic soils are due to high contents of exchangeable sodium and low hydraulic conductivity. The hydraulic conductivity measurement provides an indication of relative water transmission rate of the soil and depends on many factors, especially the volume of drainable pores. Data in Table (12) showed that the value of hydraulic conductivity was increased as a result of applied gypsum. This could be attributed to the decrease of ESP, ECe and bulk density values in the treated soil which were lower than those in the untreated soil as well as the production of high amount of soluble calcium enhanced the soil aggregates, consequently improving physical soil properties and the dynamic soil water movement (Mansour, 2012).

Furthermore, surface applied water would pass through the surface applied amendment and infiltrate the top layers allowing exchange process between $\mathrm{Ca}^{++}$ and $\mathrm{Na}^{+}$(El-Sharawy et al., 2008).

\section{c) Soil Penetration Resistance (P.R)}

Penetration resistance was measured with a cone number (1) and cross-sectional area of $1 \mathrm{~cm}^{2}$.Mean values of the penetration resistance in the surface layer throughout two seasons were presented in Table (12). The data showed that the P.R. was decreased with application of gypsum as soil amendments for surface layer. This could be attributed to the decomposition of gypsum and increasing both soluble and exchangeable calcium which enhanced the soil aggregates and increased both of total porosity and drainable pores. These results were similar with that reported by (Mansour, 2012 and Abd El-Hamid, 2011).

\section{CONCLUSION}

From the mentioned above discussion, it could be concluded that using :
1-Application gypsum to salt affected soils promotes the use efficiency of $\mathrm{N}$-fertilizer.

2-Application gypsum improving some soil physio-chemical properties.

3-Application of 4 ton gypsum fed ${ }^{-1}$ gypsum and $90 \mathrm{Kg} \mathrm{N}^{-1}{ }^{-1}$ with inoculation gave the highest increments of yield quantity and quality.

4-Inoculation with nitrobein was resulted significant increases in plant height, fresh and dry yield, and crude protein content compared to untreated.

\section{REFERENCES}

Abd- El-Hamid, Azza R., S.F Mansour, T.A. EL-Maghraby and M.A.A. Barky (2011). Competency of some soil amendments used for improvement of extreme salinity of Sahl El-Tina, soil J. Soil Sci. and Agric. Eng. Mansoura Univ., 2 (6): 649-667.

Afzal, M., A. Ahmadi and H. Ahmadi (2012). Effect of nitrogen on growth and yield of sorghum forage (Sorghum bicolor L.) moench cv. under three cuttings system. Cercetări Agronomiceîn Moldova Vol. XLV, No. 4 (152).

Alcoz, M.M., F.M. Hons and V.A. Haby (1993). Nitrogen fertilization, timing effect on wheat production, nitrogen uptake efficiency and residual soil nitrogen.Agron. J., 85: 1198-1203

Alias, A., M. Usman, E. Ullah and E. A. Waraich (2003). Effects of different Phosphorus levels on the growth and yield of two cultivars of maize (Zea mays L.).Int.J.Agric. and Biolo.5(4): 632-634.

Almodares, A., M. Jafarinia and M.R. Hadi (2009). The Effects of Nitrogen Fertilizer on Chemical Compositions in Corn and Sweet Sorghum.American-Eurasian J. Agric. \& Environ. Sci., 6 (4): 441-446.

Amandeep, S. (2012). Forage quality of sorghum (Sorghum bicolor) as influenced by irrigation, $\mathrm{N}$ levels and harvesting stage. Indian J. Sci. Res. 3(2): 67-72

A.O.A.C. (1990). Official Methods of Analysis. 15th Ed., Association of Official Analytical Chemists, Virginia, USA. 
Ashiono, G.B., S. Gatuiku, P. Mwangi and I.E. Akuja (2005). Effect of nitrogen and phosphorus application on growth and yield of dual-purpose sorghum (Sorghum bicolor (L) Moench), El291, in the dry highlands of Kenya. Asian I. Plant Sci., 4: 379-382.

Ayub, M., M.A. Nadeem, M.S. Shararand and N. Mahmood (2002). Response of maize (Zea mays L.) fodder to different levels of $\mathrm{N}$ and P. Asian J. Plant Sci. 1: 352-354.

Çakmakç, R., F. Dönmez, A. Aydın and F. Sahin (2006). Growth promotion of plants by plant growth-promoting rhizobacteria under greenhouse and two different field soil conditions. Soil BiolBiochem 38: 1482-1487.

Çakmakç, R., M. Erat, Ü. Erdogan and M .F. Dönmez (2007). The influence of plant growth-promoting rhizobacteria on growth and enzyme activities in wheat and spinach plants. J Plant Nutr Soil Sci 170: 288-295

Canbolat, M.Y., K. Barik, R. Çakmakçı and F. Sahin (2006). Effects of mineral and biofertilizers on barley growth on compacted soil. ActaAgric Scan (B Plant Soil Sci) 56: 324-332.Moench), El291, in the dry highlands of Kenya Asian I. Plant Sci., 4: 379-382.

Carletti, S., C.E. Rodriguez and B. Liorente (1996). Effect of biofertilizer application on Jojoba cultivation. Assocition for the Advan.ofIndust.Crop. (1996): 53-55 (C.F. Hort. Abst., 1997,67(2):1599).

Cottenie, A., M. Verloo, L. Kiekens, G. Veighe and R. Amertynck (1982). Chemical analysis of plants and soils laboratory of Analytical and Agrochemistry State. University, Ghent, Belgium., PP.100-129.

Custic, M., M. Poliak and T. Cosic (1994). Nitrate content in leaf vegetables as related to nitrogen fertilization in Croalia. Acta Horiculturae, 371:407-412.

Dubois, M.K.A., H. J. Gilles, R. Rebers and F. Smith (1956). Colourimetric method for determination of sugars and substances. Ann. Chem., 28:350.

EL-Masry, A.A.Y. (2001). Effect of some soil amendments and fertilizer application practices on the yield of some crops under salt affected soils.Ph.D.Thesis, Fac. of Agric., Al-AzharUniv.A.R.E.

El-Sharawy, M.A.O., M.M. El-Bordiny and S.A. Abdel-Wahed (2008). Improvement of a salt affected soil in Bahr El-Bakar area using certain industrial by-products: 1. Effect on physical and chemical characteristics. J. Appl. Sci. Res., 4(7):839-854.

F.A.O. (1995). Improvement and Production, Drainage and Salinity. An international source book. Paris.

Fathi, A.I., S.A.I. Ismail, Eisa and M.O. Easa (2003). Effect of nitrogen Sulphur and boron fertilization on growth,yield and quality of canola Egypt J.App.Sci.,18 (8):317 - 329.

Giller, K.E. (2001). Nitrogen Fixation in Tropical Cropping Systems, 2nd/Ed. CAB International, Wallingford, UK, $423 \mathrm{pp}$.

Gomez, K.A. and A.A. Gomez (1984). Statistical Procedures for Agricultural Research.John Willey \& Sons, New York, USA. J. of Agron. 5 (3): 5I5-518.

Hathout (1987). Production and management of dairy cattle in Egypt. Egyptian - Holland Workshop, Animal Production Res. Inst., March, 30-31, Cairo, Egypt.

Hassan, A. F. (2003). Using an integrated approach to introduce fertilizer recommendations in some Egyptian soils. Ph.D. Thesis, Fac. Agric., Al- Azhar Univ.

Issam, I. B. and A.H. Sayegh (2007). Methods of Analysis for Soils of Arid and Semi-arid Regions.F.A.O. Rome, Italy.

Javaid, A. and N. Mahmood (2010). Growth, nodulation and yield response of soyaben to biofertilizers and organic manures. Pak J Bot 42: 863-871.

Khalid, M., I. Ahmad and M. Ayub (2010). Effect of Nitrogen and Phosphorus on the Fodder Yield and Quality of Two 


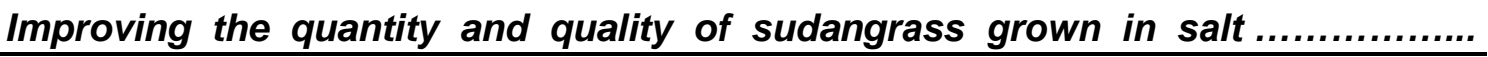

Sorghum Cultivars (Sorghum bicolor L). Int. J. Agri. Biol., 5(1):61-63.

Kusvuran, A., Y. Ralice, S. aglamt and T. Mur (2014). Determining the Biomass Production Capacities of Certain Forage Grasses and Legumes and their Mixtures under Mediterranean Regional Conditions.Acta Advances Agric. Sci., 2: 13-24.

Larkin, R.P., D.L. Hopkins and F.N. Martin (1993). Effect of successive watermelon plantings on Fusariumoxy sporum and other microorganisms in soils suppressive and conducive to Fusarium wilt of watermelon. Phytopathology, 83: 1097-1105

Lazarovls, G. and J. Nowak (1997). Rhizobacteria for improvement of plant growth and establishment. Hort Science, 32 (2): 188-192.

Manyong, V.M., K.O. Makinde, N. Sanginga, B. Vanlauwe and J. Diels (2001). Fertilizer use and definition of farmer domains for impact-oriented esearch in the northern Guinea Savanna of Nigeria. Nut.Cycl.Agroecosyst., 59: 129-141.

Mansour, S.F. (2012). Comparative effect of some industrial wastes as soil conditioners on some physiochemical hydro physical soil properties and maize productivity.Minufiya J.Agric.Res.2:387396.

Mansour, S.F., M.M.A. Reda, M.M.H. Hamad and E.G. Abo-Elala (2014). A cComparative studyof some soil amendments and their applied methods on the amelioration of saline-sodic soils.Minufiyj.Agric.Res, ,39 (2):765-774 .

Marschner, H. (1995). Mineral nutrition of higher plants.Second Edition. Academic Press, London, p. 897.

Mousavia, S.G.R., M. J. Seghatoleslamia and R. Arefib (2012). Effect of $N$ fertilization and plant density on yield and yield components of grain sorghum under climatic conditions of Sistan, Iran.Plant Ecophysiology, 4: 141-149

Naidu, R. and P. Rengasamy (1993) . Ion interactions and constraints to plant nutrition in Australian sodic soils. Australian of Soil Res. 31: 801-819.

Osman, A.S., R.M. El-Shahat and H. M. Seyam (2000). Response of wheat to fertilization treatments of nitrogen, azolla and micro-nutrients. Fayoum J. Agric. Res. \&Dev., 14 (2) : 68-74.

Oster, J.D. and H. Frenkel (1980). The chemistry of the reclamation of sodic soils with gypsum and lime. Soil Sci. Soc. Am. J., 44:41-45.

Page, A.I., R.H. Miller and D.R. Keeney (1982). Methods of Soil Analysis. Part 2: Chemical and Microbiological Properties. 2 nd Edition, Agronomy Monograph, No. 9, Amer. Soc.OfAgron Madison, Wisconsin, U.S.A.

Rashid, M. and M. lqbal (2011). Response of sorghum (Sorghum bicolor L.) fodder to phosphorus fertilizer on torripsamment soil. J. Animal \& Plant Sci., 21(2): 220225.

Russell, E.W. (1973). Soil conditions and plant growth $10^{\text {th }} \mathrm{Ed}$., Longman Group, L,T,D.

Şahin, F., R. Cakmakç and F. Kantar (2004). Sugar beet and barley yields in relation to inoculation with $\mathrm{N}$-fixing and phosphate solubilizing bacteria. Plant Soil, 265: 123129.

Salem, F.S. (2003). Effect of some soil amendments on the clayey soil properties and some crops production. MinufiyaJ.Agric.Res.28(5):1705-1715.

Samia, O. Y and A. K. Abd-elsalam (2010). Effect of nitrogen and seed rates on growth and yield of forage sorghum (Sorghum bicolor L Moench cv.Abusabien). J. Sci. Tech.,11 (2)123136.

Yazdani, M., M.A. Bahmanyar, H. Pirdashti and M.A. Esmaili (2009). Effect of phosphate solubilization microorganisms (PSM) and plant growth promoting rhizobacteria (PGPR) on yield and yield components of corn (Zea Mays L.). World Academy of Science, Engineering and Technology, 49: 90-92. 


\section{تحسين إنتاجية وجودة حشيشة السودان فى الاراضى المتاثُه بالأملاح بأستخدام الجبس} الزراعي والتسميد الحيوي

\section{عزه خليل سالم (1) ، فادية محمد سلطان (1) ، سهام يوسف محمد ابو ستيث(2)}

(1) قسم بحوث محاصيل العلف- معهد بحوث الدحاصيل الحقلية ـالجيزة -مصر

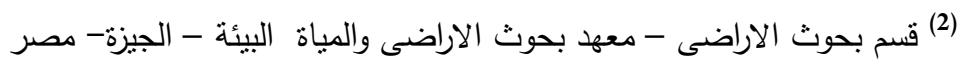

اجرى البحث فى محطة البحوث الزراعيه بالسرو بمحافظة دمياط خلال موسمى النمو 2014 و2015

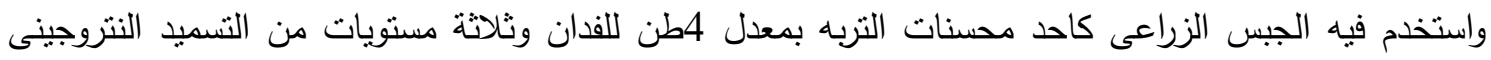

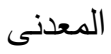

( 30 و60 و 90 كجم نيتروجين للفدان ) مع استخدام النتروبين كتسميد حيوى ازوتى ( تلقيح - بدون تلقيح )

$$
\text { تحت ظروف الاراضى الملحية. }
$$

الهدف من اجراء التجربة زيادة محصول حشيشة السودان فى تللك الاراضى وتحسين صفاته و خواص التربه الطبيعيه والكميائيه والحيويه باضافة الجبس الزراعى (احد محسنات التربه ) فضلا عن تقنين التسميد الازوتى وتقليل كميته باستخدام التسميد الحيوى ( النتروبين ) •

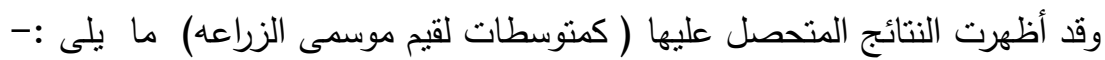

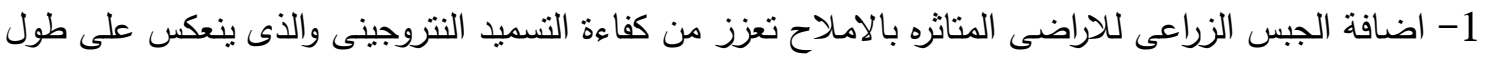

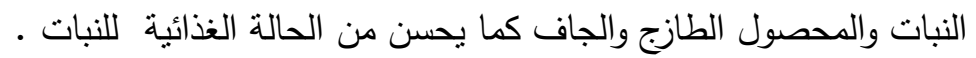
2- وقد أدى اضافة الجبس الزراعى الى خفض قلوية وملوحة التربه نتيجه لنقص املاح الصوديوم الذائبه والمنبادله وزيادة املاح الكالسيوم الذائبه والمتبادله على أسطح معقدات التربة. 3- وقد وجد ان استخدام 60 كجم من النتروجين المعدنى مع التسميد الحيوى أعطى نتائج مثقاربه غير معنويه مقارنه باستخدام 90 كجم نيتروجين بدون استخدام التسميد الحيوى تحت نفس معدلات اضافة الجبس الزراعى.

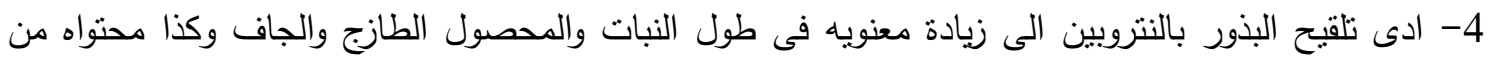
البروتين مقارنة بالمعاملات غير ملقحه. 